Unity Journal

Vol. III, 109-120, 2022

Doi: https://doi.org/10.3126/unityj.v3i01.43319

Prithvi Narayan Shah Research Center

Directorate General of Military Training, Nepali Army

Kathmandu, Nepal

\title{
How Can Classical War Philosophies Solve Modern Security Challenges?
}

\section{Umesh Gurung Shrestha}

\section{Abstract}

As the world is moving into the third decade of the 21st century, it is ever more filled with uncertainties and complexities per se. The scope of security agencies has grown beyond just protecting the state from external and internal security threats. Instead, military forces have to face a whole new domain of security challenges, unlike those from a few centuriesago.Irregularandhybridwarfarehas replaced the conventional way of battlefield confrontation between the state armies. The global rise in insurgency, terrorism, civil wars, failed states, and humanitarian crises have made the security landscape even more volatile. In this context, modern problems require modern solutions. However, most of these contemporary solutions to our security challenges can be traced back to classical war philosophies. This article attempts to explain the emerging forms of conflicts and irregular security threats, and how those war theories and strategies are more effective in managing them. It starts by reviewing the key ideas of selected classical military thinkers such as Sun Tzu, Machiavelli, Frederick II, Clausewitz, Jomini, and Liddell Hart. The latter part of the article discusses their present relevance and analyses recurring American experiences with low-intensity conflicts like insurgency and terrorism from the perspective of classical war philosophies. It is observed that the statesmen and military planners of today can still find inspiration in the age-old battlefield concepts, such as political-military relationship, intelligence, deception, indirect approach, battle avoidance, and center of gravity, to resolve conflicts and improve the condition of global peace.

Keywords: conflicts, insurgency, military, philosophy, security, strategy, terrorism, warfare

\section{Setting the Background}

The history of the world is built on wars and conflicts. The outcomes of war significantly affect the international order and the condition of global peace. Although states no longer fight conventional warfare, the military forces and law enforcement agencies today have to deal with a different breed of security threats within and beyond borders. Non-state actors like terrorists and insurgents are increasingly shaping fourth-generation warfare (4GW). As a result, the current security landscape has become quite volatile, uncertain, complex, and ambiguous (Kuo, 2007). This entirely new domain of security challenges is unlike anything the states had witnessed before.

Despite the advancement of information technology and revolution in military affairs, the basic nature of war has remained the same throughout the ages. Much of the analogies 
to contemporary security challenges can be traced back to classical war philosophies. Modern history has little to offer when it comes to prescribing appropriate strategies for irregular and hybrid war scenarios. The American experiences with Vietnam, Iraq, and recently, Afghanistan show that warfare requires strategic rethinking. The surge in global and regional terrorism, insurgency, civil wars, failed states, and humanitarian crises constitute the face of security challenges in the 21 st century. But the current and future developments in the conduct of warfare will always carry the tints of ancient and medieval history (Grygiel, 2014).

Analyzing the strategic environment from the eyes of classical war strategists offer more effective solutions to modern-day conflicts rather than just leaving it to the fate of trial and error. Such war philosophies are not only applicable in battlefield and military academies but, most importantly, statecraft (McNeilly, 2015). History is forever indebted to the ideas put forth by great military thinkers such as Sun Tzu, Machiavelli, Clausewitz, and others. Most of these treatises are centuries old but still offer a timeless piece of advice that is relevant today.

This article attempts to appreciate the classical war philosophies and examine how they contribute to understanding the evolving dimensions of security. The following section organizes and reviews the selected strategic thoughts. Then it proceeds to discuss and analyze their continuing relevance in the light of modern security challenges, especially insurgency and terrorism. An extensive portion of secondary resources, like books, journal articles, magazines, and such, were consulted by the author to address the research question and justify the topic.

\section{Decoding Classical War Philosophies}

War philosophies are the means of gaining insight into the complex phenomenon of modern warfare. They provide a conceptual framework to understand the nature of emerging security challenges and provide strategic guidelines to resolve the current and future security problems. Classical war philosophies are rich in wisdom, but they are hard to interpret at the same time. This section briefly discusses the key war strategies and theories penned and practiced by notable military thinkers like Sun Tzu, Machiavelli, Frederick the Great, Clausewitz, Jomini, and Liddell Hart.

\subsection{Sun Tzu}

Sun Tzu is the greatest war philosopher of all time. His classic work on The Art of War is still as relevant as when he first wrote it almost 2500 years ago. It is a must-read philosophy in military academies across the globe. Today, its principles have grown beyond the scope of military warfare to address crises and conflicts faced by modern societies and states.

The Art of War describes how to be victorious in decisive battles and wars. Surprising as it may seem, Sun Tzu was not a big fan of direct military confrontation. Instead, he focused on the philosophy of winning without fighting and recommended the use of statecraft by means of political, diplomatic, and economic efforts to ensure the state's victory. He believed that war should be used as a last resort and advocated an indirect approach to exploit the flaws and weaknesses in the enemy's plans and strategy. This is known as "wise war strategy", where military means are used in non-combative methods to overwhelm the enemy with surprise, speed, 
deception, and intelligence to win the battle before it begins (McNeilly, 2015).

As mentioned in the preceding paragraph, Sun Tzu placed greater importance on the use of intelligence and deception to win wars. War is a mind game that could be won by distorting the opponent's perception of reality. For instance, when able to attack, you must seem unable to do so; when nearby, give them the impression that you are far away, and vice-versa (Critzer, 2012). Eventually, the successful execution of these strategies depends on the nature of military leadership. Throughout The Art of War, Sun Tzu has emphasized the role of a general or leader, his appointment, and professional independence which is central to understanding the nature of political and military relationships even today. This is further illustrated later in the article.

\subsection{Niccolò Machiavelli}

Machiavelli (1460-1527) marked a period of transition from ancient warfare to the medieval and successive modern era of political thought. According to him, victory was the only thing that mattered in war. Therefore, the commander should not hesitate to use any means possible to defeat the enemy completely if it ends the war quickly. In his own words, war should be short and sharp. Although his ideas were morally controversial at the time, he triggered a wave of changes in the theory and practice of contemporary warfare.

Machiavelli pushed for military reforms by associating warfare with policy matters of the state. He considered confidence, loyalty, and discipline as the preconditions to victory in war. Therefore, he emphasized that the government should have a citizenarmy composed of its own citizens through conscription, who were more reliable and obedient than the hired mercenaries (Gilbert, 1986).

Machiavelli's works on The Prince, The Art of War, and The Discourses were revolutionary in their own right. Even when war tactics improved technologically over the years, his theories remain relevant. Although widely shunned by critics, his ideas were admired by Clausewitz, who deemed him to possess sound judgment in military matters. A rather critical man himself, Clausewitz recognized Machiavelli's idealism in forming his own.

\subsection{Frederick the Great}

Frederick the Great (1712-1786) laid the foundation of modern Germany during his rule as the Prussian King in the 18th century. His military strategies featured the perfection of ancient warfare and the beginning of a modern era of combat with the French Revolution. As a philosopher-king, Frederick portrayed himself as anti-Machiavellian, arguing that statecraft should be driven by ethical values and means should be balanced with ends (Gray, 1999).

The Prussian army reached the height of its military glory during Frederick's regime. $\mathrm{He}$ advised his generals to befriend the neutral countries against the common enemy and always wage an offensive war. The attack should be deliberately planned, wellrehearsed, and perfectly executed. All the while, the operation should remain highly confidential (Phillips, 1985).

Frederick introduced several military reforms by focusing on the composition and discipline of his military. He valued the quality of the army over its quantity. While he took good care of his soldiers, he also put a tight leash on the troop. His practical model of statecraft 
inspired successive generations of military generals and theorists and continues to shape the modern world order even today.

\subsection{Carl von Clausewitz}

Carl von Clausewitz (1780-1831) was a Prussian military general who wrote extensively on war and strategy based on the observation of Napoleon and Frederick's military campaigns. His On War still remains the most detailed and influential war treatise to date. Clausewitz (1832, as cited in Paret, 1986) stressed the political nature of war, stating that "war is a mere continuation of politics by alternative or military means" ( $p$. 200). The political goal must be clear before waging war. He viewed military forces as means to political ends. There is too much at stake to leave warfare as an autonomous military act. Therefore, Clausewitz argued for domination of political leadership over military objectives in the conduct of war.

This political-military relationship reveals three main elements of war, viz. the people, the military, and the government, collectively known as the "trinity of forces." Each of them has its own tendency of war. The popular opinion and attitude of people, professional military capabilities, and the policy direction of the government interact with each other to determine the nature and progression of events in war (Howard, 2002).

One of the key tenets in Clausewitz's strategy is the "center of gravity." He believed wars could bewon by attackingat theenemy's source of strength with speed and concentration of forces. However, Clausewitz warns against getting carried away with victory to the extent of exceeding the "culminating point." If the military pushes its offense beyond the culminating point of attack, it will not be able to maintain a strong defensive position (Gray,
1999). The wisdom lies in knowing when to stop. In general, Clausewitz did not attempt to define warfare in terms of a specific set of military instructions. The philosophical approach in writing On War makes his work unique and timeless, which is still applicable in the context of modern security challenges.

\subsection{Antonie Henri de Jomini}

As a contemporary of Clausewitz, Antonie Henri de Jomini (1779-1869) provides an eye into the transformation of warfare during the Napoleonic era. He wrote and published several books on military strategies for which he is regarded as the father of modern strategy. His work on the Summary of the Art of War published in 1838, is the most remarkable contribution to modern military theories and practice.

Jomini was a master strategist and practitioner of war himself. He wrote extensively on the operational and tactical levels of war. He perceived the battlefield in geometrical terms and preferred to call it the "theater of operations." Like Clausewitz's center of gravity, Jomini believed that the fundamental principle and key to success lie in concentrating forces at the enemy's decisive points. In other words, he emphasized striking with greater offensive force at the weakest and most vulnerable point of the enemy to create maximum damage (Malik, 1999).

Similar to Sun Tzu, Jomini was also aware of the complex nature of political and military relationships. He argued that military leadership should be independent to take care of military matters without any political or bureaucratic interference. Jomini was largely driven by the desire to create a system for waging wars successfully. Though not without flaws, his theories and principles still influence military thought and practice. 


\subsection{B. H. Liddell Hart}

As uncertainty was looming over the conduct of warfare during the First World War, Basil Liddell Hart (1895-1970) emerged as an influential military strategist in the western world. He was particularly critical of Clausewitz's offensive approach to war that led to devastating consequences. Against this backdrop, Liddell Hart echoed Sun Tzu and Jomini, stating that war must be fought intelligently, effectuating, as a consequence, the least damage possible.

Liddell Hart was the mind behind the indirect approach and mechanized warfare (blitzkrieg) in the Second World War. $\mathrm{He}$ focused on the strategy of least resistance to achieve an advantageous position, rendering battles unnecessary for a decisive victory. His contribution to military thought lies in reorganizing Sun Tzu's ideas of surprise, speed, deception, and intelligence in the form of an indirect approach to war. $\mathrm{He}$ was against direct confrontation because it triggers resistance from the other side. Instead of striking with greater force at the enemy's center of gravity, it is wise to take the least expected route or the line of least resistance (Malik, 1999). His thesis of the indirect approach serves as a blueprint for 21stcentury strategic decisions securing a special mention in modern strategic discourse.

It is worth noting here that strategy is not just about winning wars; it is about resolving conflicts and ensuring lasting global peace and order. But there seems to be a lack of consensus regarding its approach. Without consolidating these different philosophies, it is impossible to effectively find a way out of the modern security crisis.

\section{Understanding Modern Security Challenges}

The global security environment has changed drastically over the centuries. An alliance of world power has ensured peace to a certain level, but many security challenges still exist. Although wars may no longer be fought conventionally, the states still find themselves tangled in conflicts within and beyond borders. New forms of security threats are emerging, which are multidimensional in nature with far-reaching consequences that cripple the nation-states. As a result, the modern security landscape is becoming increasingly volatile, uncertain, complex, and ambiguous, abbreviated as VUCA (Kuo, 2007).

The world order has become quite dynamic after the Second World War. States no longer seem to wage active wars but continue to rock the boat with proxy wars, further stretching the grounds for conflicts. The United States of America dragged itself into the Vietnam War (1955-1975) which turned out to be one of the bloodiest conflicts in the history of warfare. America is still unable to justify its involvement in Vietnam. The whole country was divided on whether the war was necessary at all (Tucker, 2011). On top of that, the U.S. military suffered badly despite being heavily armed compared to Vietnamese guerrillas. This marked the evolution of unconventional irregular and hybrid warfare that has become a de facto form of confrontation between the states today.

The Soviet Union had a bitter experience with Afghanistan in the 1980s that eventually led to its collapse in 1991. There was a significant increase in insurgency and terrorism in the following years, notably the rise of Osama bin Laden and his al-Qaeda. The 9/11 attack 
on the World Trade Center turned out to be a major eye-opener, not only for the U.S. government and military but for the entire world. Subsequently, America declared the "War on Terror" and invaded Afghanistan in 2001. After 20 years of fighting against the Taliban insurgents, it proved to be yet another strategic failure on the part of America. Everything is back to ground zero.

Modern warfare has grown beyond the scope of Clausewitz's trinity of forces. Non-state actors like terrorists, insurgents, warlords, militias, and private security contractors are increasingly shaping the conduct of warfare while the states are taking a back seat (Jordan et al., 2016). This evolution of terrorism and insurgency mark the Fourth Generation Warfare (4GW). According to Martin van Creveld (1991, as cited in Sloan, 2012, p. 71), the post-colonial world saw an increase in the number of low-intensity conflicts that have led to a rise in the number of failed states, humanitarian crises, and civil wars. Military intervention alone is not enough to deal with this situation because war is no longer fought by the states and armies but rather by insurgents, terrorists, and guerrillas. Unlike conventional warfare, the $4 \mathrm{GW}$ requires the use of all aspects of national power (political, economic, social, and military) to resolve conflicts effectively (Critzer, 2012).

The main security challenge for modern societies, states, and armies is hybrid in nature. Russia's annexation of Crimea and the ongoing tensions with Ukraine and NATO, the Syrian Civil War, and the emergence of ISIS are a few contemporary instances of hybrid warfare in the 21st century (Cîrdei, 2017). This situation calls for a rethinking of strategies and tactics to solve the modern security challenges. Classical war philosophies offer a better solution.

\section{Return of Classical War Philosophies in Modern World}

As the new form of conflicts and irregular security threats continue to rise globally, the study of warfare has become even more critical. Wars are fought with arms but won with strategies and tactics. The classical military ideas discussed earlier in the article have withstood the test of time. Although the battlefield dimension has changed significantly in recent decades, several strategic concepts retain their validity even in the face of modern security challenges.

\subsection{Political and Military Relationship}

Military forces and security agencies are built on a strictly defined chain of command featured by the principle of unity of command. This authoritative culture is inducted into the cadets from the basic training throughout their service. However, the complex politicomilitary relationships in the matters of national security and war undertakings make it difficult for the military to maintain their political effectiveness (Lamb, 2010). A wellfunctioning state is defined by the nature of the relationship between its military and political establishment. There is a long-standing debate regarding each of their respective roles in statecraft and warfare. Military plans and actions have to align with the policies of the government. It is the role of the political leadership to create a favorable environment for its army and provide strategic direction during crises and wartime (Malik, 1999). Machiavelli's push for conscription to raise a disciplined and loyal citizen-army highlights the importance of political direction in organizing and mobilizing the military for enhancing national security as a whole.

However, this relationship should not be confused with the political micromanagement 
of military affairs. This is exactly what happened in the Vietnam War. The then U.S. President Lyndon Johnson and his secretary of defense, McNamara, went over the lines in calling shots during the war. Johnson had every right to do so as the commander in chief, but he overplayed his role. They maintained close supervision over the details of war-making that limited the role of military commanders on the battlefield. Johnson often reviewed the target lists to be hit by the U.S. bombers, limited the number of raids and sorties, and even imposed rules of engagement (RoE) for the soldiers. Such political considerations seriously crippled the effectiveness of the U.S. troops. Johnson and his staff made a mess out of the global military superpower by sending the military to fight with one hand tied behind their back (Cohen, 2012).

However, it is not desirable to leave matters of war entirely to the discretion of military authorities alone. Modern security challenges, like insurgency and terrorism, are increasingly becoming political. The ultimate goal is longlasting peace, not violence. The use of military force is not always the answer. Clausewitz viewed war as a continuation of politics, thus a political objective, and the military as only the means to an end. Frederick rejected the Machiavellian idea of ends justifying the means because it disturbed the international order and promoted a vicious circle of war. Victory without balance between means and ends might lead to consequences as bad as that of defeat (Gray, 1999).

The role of political leadership should be to reduce the friction of war, not exacerbate it with excessive interference. Therefore, instead of overriding military leadership, Clausewitz saw greater value in a collaborative effort where each plays their respective role.

\subsection{Trinity of Forces}

When a state goes to war, it is not only the army that is involved but also the government and the people. In other words, the nature of war can be understood in terms of the trinity of forces, including the people, the military, and the government. According to Clausewitz, each of them represents dominant tendencies of war that define its dynamics. The 9/11 attack and the Bush Administration's declaration of the Global War on Terror reignited the significance of Clausewitzian Trinity in the 21 st century. Due to the prevalence of nonstate actors in insurgency and terrorism, the primary trinity of forces (passion, chance, and reason) is more relevant than the secondary trinity (people, military, and government) in irregular warfare. Security crisis appears, and then war breaks out when the equilibrium in this trinity is disturbed. Therefore, this trinity of forces works as a framework in understanding the nature of modern security challenges.

These forces should remain in balance at all times to provide strategic direction guidelines for decisive operations. Although America went to war with massive international support and popular will, there was no clear understanding of what they hoped to achieve. Failing to learn from the Vietnam War, America went knee-deep in Afghanistan without good reason and lost public support for its military actions (Fleming, 2016). For most Americans, the involvement in Afghanistan was simply not worth it. As a result, the trinity collapsed, and the Afghan war turned out to be yet another strategic failure for the global superpower.

The context and actors of war have changed, but its nature remains the same. The conditionbased approach considers the entire spectrum 
of war to include all actors (both state and non-state) and the intensity of conflicts, notably in the Middle East. This approach marks the departure from traditional threatbased or "who is the enemy" to capabilitiesbased strategy, focusing on "how" the enemy fights (Glavy, 2002). This holistic approach to defensive strategy can help the security forces to develop, maintain, and enhance their capabilities to solve future security challenges.

\subsection{Use of Indirect Approach}

The threat of a nuclear war has been imminent in recent times. While it is impossible to envision how future conflicts may occur, it is most likely to be won by the side that can mobilize its military prowess accurately, dismantling the enemy's center of gravity without provoking resistance from the opposition. This strategy of penetrating the enemy at its core and dislocating its defenses is not new. Like Sun Tzu, LiddellHart emphasized the psychological aspect of conflict to formalize and practice tactics that he dubbed as indirect approach (Malik, 1999).

Being armored with the latest weaponry is not the only factor that determines one's victory. In fact, the consequences may be just the opposite. Wars and conflict can be averted altogether with the use of the indirect approach. The Cuban Missile Crisis serves as an embodiment of this classic military tactic. The then U.S. President John F. Kennedy could have reacted to the threat by directly invading the Latin American country. Instead, he made the rational choice as prescribed by Sun Tzu and Liddell Hart's ideas of an indirect approach to avoid the escalation of the Cold War into a nuclear war by pledging not to invade Cuba (McNeilly, 2015). A strong military presence is favorable but not at the cost of a cataclysm. Commanders must know when to practice their military supremacy and when to withhold. In insurgencies, the primary goal is not to control territory but to win the hearts and minds of the population affected by the conflict.

An indirect approach is relevant even today as one can subdue their enemy into defeat before the battle begins. At the strategic and operational level, the troops that implement elements of speed, surprise, and deception can fight and win a low-intensity conflict.

\subsection{Intelligence and Deception}

As discussed earlier, wars are not won solely based on military force. Going to wars without the right information can have serious, long-term consequences. The U.S. invasion of Iraq in 2003 was the result of basic intelligence failure. The U.S. intelligence agencies alleged that Saddam Hussein's team was developing weapons of mass destruction (WMD) and had ties with al-Qaeda. Sparsely informed U.S. President George W. Bush (2003), then sanctioned the Iraq invasion and sent a coalition of 177,194 troops for "disarmament of Iraq's WMD, the liberation of the Iraqi people, and suppression of Saddam's support for terrorism." In reality, no such weapons existed. Although the invasion started as conventional warfare, it eventually transformed into an insurgency. From Machiavelli's probing eyes, it was bound to happen as American forces lacked detailed knowledge about its physical and human terrain (Lebovic, 2010).

The U.S.-led coalition could not gather information from credible sources, spending billions in the invasion that led to nothing. McNeilly (2015) points out that Sun Tzu specifically used the term "foreknowledge" 
to understand the enemy's capabilities and intentions which is equivalent to intelligence in contemporary military jargon. Military intelligence was of great value to Jomini as well. He went one step ahead of Sun Tzu in terms of its collection and analysis. At the time when the horse was the fastest means of transportation, and the highest point of observation was a hilltop, he came up with the idea of air observation or surveillance for an advantage on the battlefield (Hittle, 1947). This closely resembles the use of drones for surveillance in modern times.

As crucial as gathering reliable intelligence is, the art of spreading disinformation is vital to staying on top of the game. Both Sun Tzu and Machiavelli advocated for the use of deception to mislead and manipulate one's enemies, thus gaining the upper hand. Pulling off a successful deception requires skill and discipline. Frederick concealed his intentions even from his own officers until the time of execution. The art of deception in the Allies was neatly arranged such that the majority of German officers were not wary of the blitzkrieg invasion until a few hours later. This element of surprise wards off the enemies and falters their attack plans.

In recent times, the practice of deception has become challenging due to democracy and a need for openness. Since all the countries are under heavy media scrutiny, deceiving the enemy can be quite difficult but not impossible.

\subsection{Battle Avoidance}

The best way to avoid the consequences of war is to avoid it in the first place. But since conflict is inevitable in human civilization, wisdom lies in knowing when to wage war and when to withdraw. War is a costly undertaking in which nations not only lose their soldiers but millions in resources. One of the biggest failures in history was the Vietnam War which lasted over 20 years. Similarly, when the Bush Administration declared the "war on terror" in 2011, it was thought to be over quickly without taking a toll on the nation's military and resources. The initial military action indicated that the victory in Iraq and Afghanistan would come soon. As the insurgency continued to increase in the Middle East, the U.S. got more involved in the conflict. Machiavelli was aware of the costs of prolonged warfare; that's why he justified the use of overwhelming force to cut the wars short and decisive. There are no strict rules in modern warfare. Sun Tzu had already diagnosed this ability of war to lead to unforeseen consequences, which is why he conceptualized the tenet of battle avoidance in his Art of War (Critzer, 2012).

Even after deciding to go to war, it should be "short and brisk" to achieve an advantageous peace as soon as possible, as prescribed by Frederick the Great. For this reason, he instructed his generals to focus on only one enemy at a time and warned against penetrating too deep into the enemy's territory. To coordinate the political-military relationship, it was necessary for him to assume the role of a soldier-king to align the military strategy with the state's policies (Telp, 2004). These classical strategies could have helped save countless lives and resources had they avoided the war or concluded it shortly. The U.S. economy took a drastic hit after the war, and a cycle of inflation was unleashed. The verdict on who won the Vietnam War is still under debate. But one thing is for certain: The Americans were outraged that soldiers were dying over a lost cause. Even those who argue the U.S. won the war agree that it was a sour victory. 
Unlearning from their experience in Vietnam, the U.S. military repeated the history in Afghanistan. It began after the 9/11 attacks, in which over 3000 people in the US lost their lives. Thus began one of the longest wars in history. Forbes (2021) reports that the cost of war in Afghanistan exceeded \$2 trillion in the last two decades. Countless civilian and military lives were lost. Over 2,500 US soldiers and more than 47,000 civilians were killed, in addition to several unaccounted casualties. The war was simply not worth it. Following the exit of American troops, the country has once again been ruled by Taliban militants, rendering the past 20 years' worth of army endeavors futile. The war was a strategic failure that could never be won (Seldin, 2021).

\subsection{Center of Gravity}

The proliferation of militant extremist groups in recent decades signifies the evolution of decentralized warfare driven by non-state actors. As a result, the concentration of violent forces at the enemy's center of gravity, as theorized by Clausewitz, is no longer a viable option because there is no definite physical point to start with (Echevarria II, 2007). Although military planners struggle with its practical application in the modern context of irregular warfare, the concept of center of gravity still holds some validity even today.

Clausewitz defined the center of gravity as the enemy's power hub that can be their armies, capital, or allies. Interestingly enough, Jomini's concept of attacking at decisive points closely resonates with Clausewitz's center of gravity. Modern strategist Admiral J.C. Wylie (as cited in Echevarria II, 2007) argues that it is not only about the strengths but also the critical vulnerabilities (p. 178). Therefore, analysis of the enemy's center of gravity is of prime importance in counterinsurgency operations to understand their sources of strengths, weaknesses, and vulnerabilities.

The center of gravity concept works both ways. Osama bin Laden and his brainchild al-Qaeda carried out one of the deadliest terrorist attacks in history. The 9/11 attack at America's economic power hub, the "center of gravity", exposed the greatest military superpower's vulnerability. The US reacted by declaring war on terror and headhunt of bin Laden who was ultimately killed in 2011. Despite his death, global terrorism is rising, and the extremist militant group is still active, led by Ayman al-Zawahiri. The center of gravity in modern conflicts is rarely physical in nature, making it more elusive and difficult to pinpoint (Gerges, as cited in Echevarria II, 2007, p.186). Al-Qaeda and other jihadist organizations are driven more by ideologies than a person. As a result, they still continue to be a threat.

The main political goal of insurgency is to gain legitimacy that depends on the will and support it receives from the population. The need to win people's "hearts and minds" is critical to conducting successful counterinsurgency operations and countering any other forms of irregular warfare. The British handled the Malayan insurgency by identifying the critical factors to defeat the enemy. These critical factors were based on the analysis of the center of gravity (guerilla forces) and critical vulnerabilities (civilian support) of the insurgents. By depriving the insurgents of their main source of popular support, the guerilla forces gradually withered (Mallette, 1997). America tried to follow a similar model of counter-insurgency operations in Vietnam but in vain. 


\section{Conclusion}

This study tries to emphasize that military prowess alone is no longer sufficient to guarantee decisive victories in modern-day conflicts and warfare. America's recurring experiences with its war on terror and counter-insurgency operations are evident of the fact that direct military confrontation is neither feasible nor desirable to deal with irregular threats and security challenges of terrorism, insurgency, civil wars, failed states, and humanitarian crises. Unlike conventional warfare, these are low-intensity conflicts increasingly dominated by non-state actors, making the contemporary security landscape more volatile and uncertain - the evolution of the $4 \mathrm{GW}$ calls for strategic rethinking in terms of contemporary theory and practice of warfare. But modern history has very little to offer in this regard. The statesmen and military planners of the 21 st century still go back to ancient and medieval history, seeking battlefield wisdom to guide their tactics and strategy.

Classical war philosophies by military thinkers such as Sun Tzu, Clausewitz, Jomini, and others have influenced the conduct of warfare throughout the centuries. By reviewing and analyzing their ideas, this study found that although they seem to contrast each other on a few grounds, it is possible to identify certain philosophies where they all come together. They offer explanations to the outcomes of war and how it could have been altered altogether. The synthesis of these classical war philosophies can be developed into a holistic body of knowledge to provide a strategic framework for understanding modern security challenges. Applying classical military perspective to analyze present-day conflicts reveals the timeless value of the centuries- old concepts, including, but not limited to, the political-military relationship, use of intelligence and deception, indirect approach, battle avoidance, the trinity of forces, and the center of gravity.

Despite the changes in the context, intensity, and actors of conflicts, the underlying nature of war and the struggle for power and legitimacy remain constant. Classical war philosophies continue to retain validity in the current and future security landscape. Historical events and experiences offer a plethora of statecraft and military wisdom to solve modern security challenges for longlasting peace. While seeking solutions to future problems, one needs to look at the past and learn from their predecessors because war is more about peace than the use of force and violence.

\section{References}

Bush, G. W. (2003). President discusses beginning of Operation Iraqi Freedom [Transcript]. The White House https:// georgewbush-whitehouse.archives.gov/news/ releases/2003/03/20030322.html

Cîrdei, I. A. (2017). The hybrid warfare in the 21st century: An old concept with a new face. International Conference Knowledge-Based Organization, 23(1), 74-78.

Cohen, E. A. (2012). Supreme command: Soldiers, statesmen, and leadership in wartime. Simon and Schuster.

Critzer, O. D. (2012). 21st century strategy needs Sun Tzu. US Army War College.

Echevarria II, A. J. (2007). Clausewitz and contemporary war. Oxford University Press.

Fleming, C. M. (2016). Clausewitz's timeless trinity: A framework for modern war. Routledge.

Forbes (2021, August 16). The war in Afghanistan cost America $\$ 300$ million per day for 20 years, 
with big bills yet to come. Forbes. https://www. forbes.com/sites/hanktucker/2021/08/16/thewar-in-afghanistan-cost-america-300-millionper-day-for-20-years-with-big-bills-yet-tocome

Gilbert, F. (1986). Machiavelli: The Renaissance of the Art of War. In P. Paret (Ed.), Makers of Modern Strategy from Machiavelli to the Nuclear Age (pp. 11-31). Princeton University Press.

Glavy, M. G. (2002). The Relevancy of the Clausewitzian trinity to the war on terrorism. Marine Corps Command and Staff College.

Gray, C. S. (1999). Modern Strategy. Oxford University Press.

Grygiel, J. (2014). The Return of Ancient Challenges. Infinity Journal, 4(2), 38-43. https://www.militarystrategymagazine.com/ article/the-return-of-ancient-challenges/

Hittle, J. D. (Ed.). (1947). Jomini and his summary of the art of war. Harrisburg Washington.

Howard, M. (2002). Clausewitz: A very short introduction. Oxford University Press.

Jordan, D., Kiras, J. D., Lonsdale, D. J., Speller, I., Tuck, C., \& Walton, C. D. (2016). Understanding modern warfare. Cambridge University Press.

Kuo, L. S. A. (2007). Sun Tzu's war theory in the twenty-first century. U.S. Army War College.

Lamb, C. J. (2010). Unity of effort: Key to success in Afghanistan. Diane Publishing.

Lebovic, J. H. (2010). The Limits of U.S. military Capability: Lessons from Vietnam and Iraq. Johns Hopkins University Press.
Malik, J. M. (1999). The evolution of strategic thought. In C. A. Snyder (Ed.), Contemporary security and strategy (pp. 13-52). Palgrave Macmillan.

Mallette, J. R. (1997). Operational Art in the Success of the Malayan Counterinsurgency Campaign. Naval War College. https://doi. org/10.21236/ada325123

McNeilly, M. (2015). Sun Tzu and the Art of Modern Warfare. Oxford University Press.

Paret, P. (1986). Clausewitz. In P. Paret (Ed.), Makers of Modern Strategy: From Machiavelli to the Nuclear Age (pp. 186-213). Princeton University Press.

Phillips, T. R. (Ed.). (1985). Roots of strategy: The 5 greatest military classics of all time. Stackpole Books.

Sloan, E. C. (2012). Modern Military Strategy: An Introduction. Routledge.

Telp, C. (2004). The Evolution of Operational Art, 1740-1813: From Frederick the Great to Napoleon. Routledge.

Tucker, S. (Ed.). (2011). The Encyclopedia of the Vietnam War: A political, social, and military history. ABC-CLIO.

Tzu, S. (2010). The Art of War: Spirituality for Conflict. Jaico. 